The Sustainable City XIV 235

\title{
PRESERVATION OF COMPANY TOWNS IN MEXICO
}

\author{
ALEJANDRO ACOSTA COLLAZO \\ Department of Architecture, Autonomous University of Aguascalientes, Mexico
}

\begin{abstract}
A company town used to be a community that included services like work and housing, but also stores. The main buildings of a company town were the enterprise buildings, but for several reasons the whole built complex - including houses - are considered as a company town. The first company town in Mexico was La Constancia Mexicana in the state of Puebla, but there were some other company towns spread out in the whole country. In this paper, some company towns situated in different states of Mexico (Oaxaca, Tlaxcala, Puebla, Jalisco and Aguascalientes) were chosen for this study. Several preservation problems were detected, for example, the city of Aguascalientes continues to grow on the western side of it; hence, changing its historic sites. So, it is important to improve historic preservation, but also pursuing prosperity around cultural sites. The newest social housing projects and private developments nearby San Ignacio company town become a problem for the future of the building; therefore, cultural sustainability becomes a priority. A preservation option that some governments have a tendency to apply is the conversion of the historic buildings to museums, but not all the cases have to do with this practice. It is through a study of the taxonomic classification of architectural characteristics of company towns in Mexico that interpretive centres can help demonstrate the importance of their conservation and regeneration. Also, they can play a part in raising historical awareness. The paper can contribute to improve social and cultural issues of a city or a state. Besides, the final results could help city planning to advance in sustainability of architectural heritage sites. Preservation of company towns in Mexico can be instrumental in developing cultural identity. Also, recognition of significant historical facts of industrial heritage can help to stop the loss of several iconic buildings.

Keywords: company towns, historic preservation, sustainability, cultural identity.
\end{abstract}

\section{INTRODUCTION}

The objectives of this paper include analysing architectural characteristics of company towns, in order to understand the way they functioned and they solved spatial conditions. Also, the main zones of each selected company town will be compared to find out about production processes and their relationship with architecture.

The communities (small cities) named company towns were based on factories that were established in the whole world during industrial revolution. Mining towns are a good example of these circumstances and also prime movers. Marais et al. [1] argue: As mining intensified after the industrial revolution of the eighteenth century, mining companies all over the world began to build and manage towns for their employees. In providing housing, infrastructure and services, these towns performed a social function. They created new communities and became distinctive features of the landscape.

In 1902, Ebenezer Howard wrote down a book, related to ideal design standards for cities, communities and factories: Garden Cities of Tomorrow, published in London by Swan Sonnenschein and Co. Ltd. But the first edition was named as To-morrow: A peaceful Path to Real Reform, published in 1998. Howard was worried about how cities were growing rapidly and mentioned them as great cities. Also, he questioned himself about the happiness of people and searched for new urbanism methods to make the country more attractive than a town. Industrial revolution caused people a preference to live in a city, rather than in the countryside.

Howard assumed a town and the country could be considered as magnets. In fact, people preferred sometimes to live in a city because location of services and places to work, but in 
the ending of the 19th century there was a lack of houses for workers. So, Howard suggested a third magnet: Town-country, where good qualities of each one could be put together to promote better ways of living for societies. Howard visualised a Town-country magnet with beauty of nature, social opportunities, fields and parks with easy access, low rents, high wages, low rates, plenty to do, low prices, no sweating, field for enterprise, flow of capital, pure air and water, good drainage, bright homes and gardens, no smoke, no slums, freedom and cooperation. Yuan et al. [2] argue a survey of studies on Garden Cities over the past 100 years suggests that Howard's theory has only been considered qualitatively.

Somehow company towns took ideas from Howard's principles. Companies could offer opportunities for workers on a specific location, and of course, company towns could be situated in the countryside and offered reduced rents for workers, considering location advantages. This means the factory and housing for workers were situated at the same place or very close to each other.

In some way or another, company towns provided their employees sanitary conditions. Usually a company town was situated close to rivers or ponds to assure water supply to produce energy and the cleaning of equipment installed in the factory. But also the running water was for inhabitants. Besides, in some company towns a pond or a lake was created for leisure activities.

Also, another capitalist who developed social ideas to improve working conditions was Robert Owen. He bought the New Lanark mill and encouraged better conditions than merely profit-making ones and the countryside was an ideal place to get them. An interesting situation was that he promoted education for his workers.

In some of the cases mentioned on this paper a small school was founded near the factory. Besides, an important contribution of Owen was the foundation of New Harmony's experimental community in Indiana in 1825. Afterwards, several working communities in the United Sates followed Owenism.

In Mexico, the first company town: La Constancia Mexicana settled in Puebla in 1835 and it didn't close until 1991. Also San Ignacio in Aguascalientes was a historical company that was built in 1861. Nevertheless, the architectural floor plans looked like the ones from company towns in Europe or from the United States of America. This situation depended also on the owner's culture and their nationality. San Ignacio company town is a good example of it. The first owner: Pierre Cornú came from France and designed his factory with architectural styles accordingly, even though an original Plan d'un batiment hasn't been found. Such company town took ideas from Howard's garden city and community concepts from Robert Owen. Obviously, in most of the company towns mentioned on this paper there were also significant historic infrastructures surrounding the factories.

\section{METHODOLOGY}

The methodology used throughout the writing of this paper started selecting a sample of typical company towns in Mexico: La Soledad Vista Hermosa in Oaxaca, La Trinidad in Tlaxcala, La María in Puebla, La Constancia Mexicana in Puebla, Río Grande El Salto in Jalisco and San Ignacio in Aguascalientes. Afterwards, drawings were made in floor plans using Computer Aided Design (CAD) systems, in this process the drawings were made using an urban scale to be able to compare them; in addition, the "area" tool of the CAD system was useful to determine specific surfaces of the companies.

Furthermore, the main structures of the company towns, drawn in CAD systems, were extruded as volumes in order to compare them. So as to obtain more accurate results, a research was done to find historic drawings of the company towns selected, and also historic information obtained from company archives. After getting the correct sizes of each factory 
- including heights, a taxonomic classification was made, based on overall similarities of the companies, also using colours on extruded volumes (original spatial use class and types of buildings), dimensions and square meters. The methodology included revising historical documents frequently to find certainty about the areas and correct zones.

The methodology used in this paper can be considered as qualitative, because historical research of architecture was practiced and also a researcher's interpretation was used. Groat and Wang [3] say the strategy of qualitative research is one of first-hand encounters with a specific and defined context. It involves gaining an understanding of how people in realworld situations "make sense" of their environment and themselves; and it depends on, rather than rejects, the researcher's interpretation of the collected data.

The method searches assets and limitations of the six company towns reviewed on this paper, but evaluation was restricted to taxonomic analysis, in order to comprehend spatial relationship of main zones built in each factory. Nevertheless, there are some other factors like geographic location and the relation to their historical context that were also considered by the author of this document.

This paper can also help to promote interpretive centres in Mexico where people can learn significant appreciations for historical company towns. Also institutions can help assemble valuable information and archives to keep business activity of company towns.

\section{HOUSING FOR WORKERS AND INDUSTRIAL HERITAGE}

During the 19th century and the beginning of the 20th century, several factories preferred to build houses for workers nearby the companies in Mexico. This is the case of textile factories, construction companies, railroad companies, mining companies, etc. Even though textile companies were very common in Mexico, also there used to be very interesting factories of some other architectural typologies and styles.

Paternalism was part of the way of living in company towns. The design of company towns included behaviours expressing attitudes of dominance; particularly in the way housing for workers was designed, for example in La Constancia Mexicana and San Ignacio. So, houses for workers were situated very close to work places (large factories) for practical reasons. The distance from home to work was insignificant, but also the company towns used to have stores, so workers didn't have to leave the place to buy provisions. However, sometimes workers couldn't afford to pay their basic needs and most of them were drowning in debt with the owners of the company towns. This situation was somehow used as a way to rule the workers and also their private lives.

There used to be a social balance in company towns - with no wealthy residents, but big houses were destined to the owners of the company or for the administrators. In fact, it can be observed that in most of the company towns analysed in this paper the houses of the owners can easily be identified; nevertheless, there used to be open spaces and squares with gardens where people could socialize with anyone. Shojae et al. [4] mention in establishing a deep mental and internal connection between the individual and the environment, it creates a sense of satisfaction and identity in him and increases the dynamism and vitality of the squares and the formation of social interactions in the residents. This was the case of San Ignacio company town.

Not all company towns in Mexico were to develop cities. In fact, some of the cases mentioned in this paper preferred to situate in isolated places with no densely-housed regions, but close to rivers, lakes or areas endowed with natural resources to ensure return of investments. Also, several company towns helped improved railway tracks and developed efficient infrastructure to communicate with cities and a nationwide network. The national 

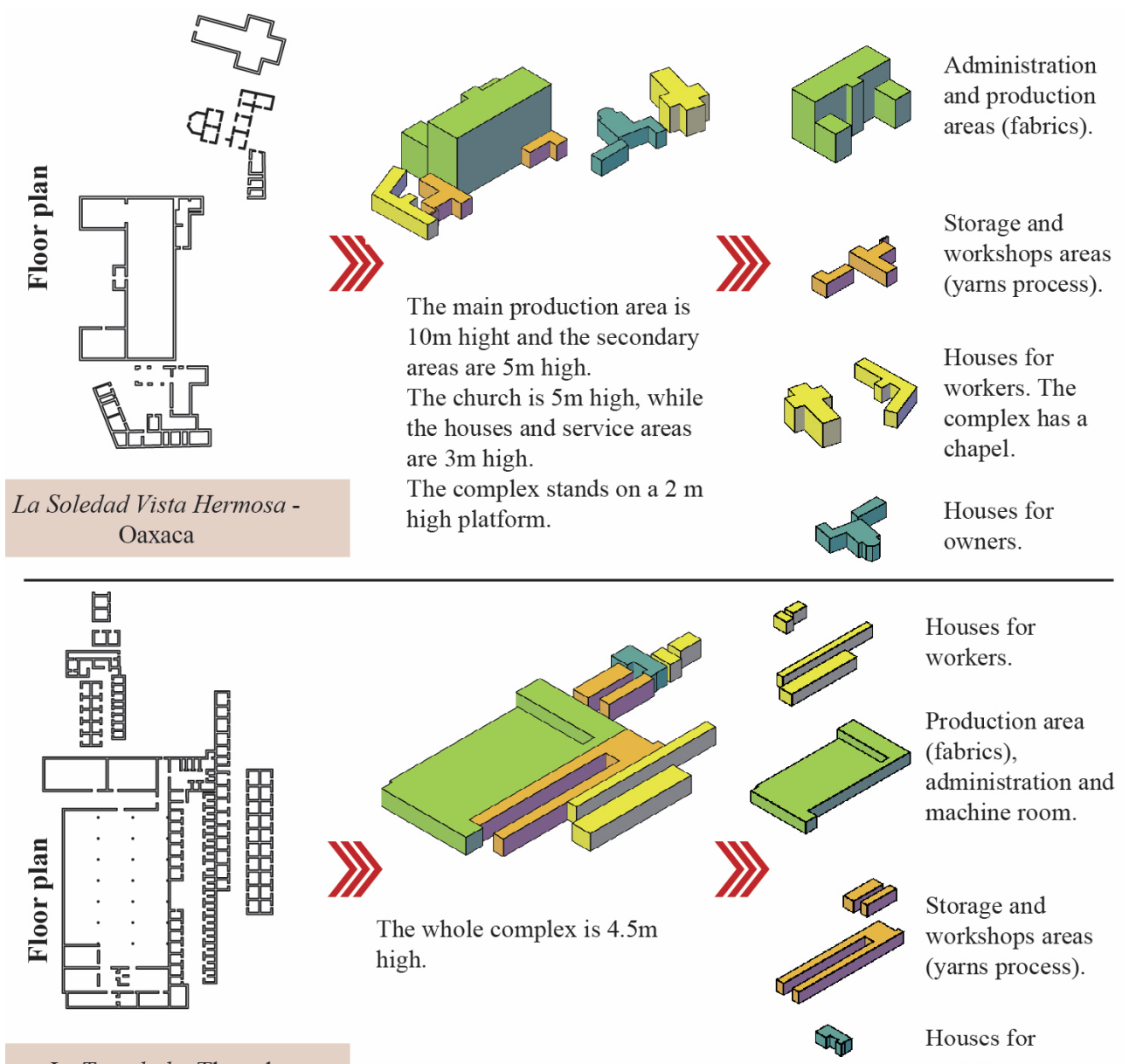

Houses for workers.

La Trinidad - Tlaxcala

The whole complex is $4.5 \mathrm{~m}$ high.

Production area

(fabrics),

administration and machine room.

Storage and workshops areas (yarns process).

Houses for owners.

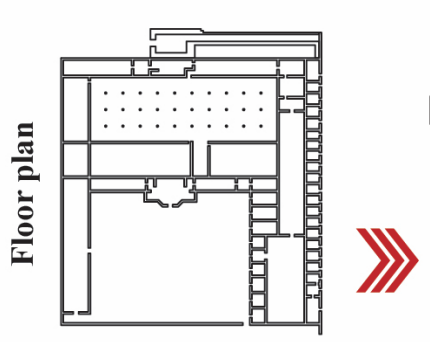

The production area is $11 \mathrm{~m}$ high. The other components are $6.5 \mathrm{~m}$ high in the whole complex.

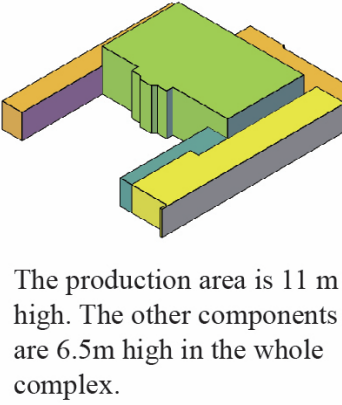

La María - Puebla

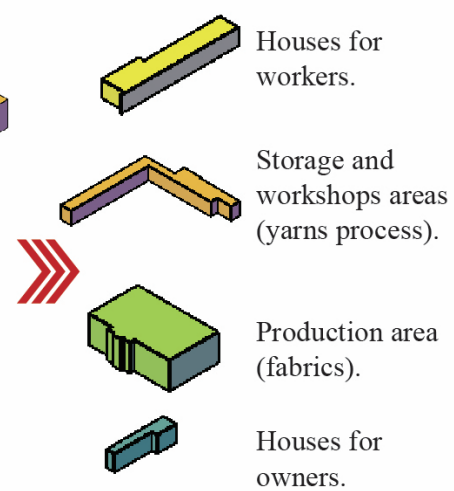

Figure 1: Sample of company towns in Oaxaca, Tlaxcala and Puebla. (Source: Drawing made by Alejandro Acosta Collazo and Adriana Guadalupe Martín del Campo Cervantes, September 2020.) 
government also promoted fair practices of manufacturers and supported connections among factories. Nowadays, land speculation has affected some company towns, for example San Ignacio. This situation has also happened lately in Europe. Camerin [5] argues: in Barcelona, the destruction of the traditional working-class neighbourhood, which evolved based on industrial and railway activities, served to make way for speculative re-development lead by financial and real-estate capital, plus private's interest retreated from community-oriented planning initiatives.

Company towns could be considered nowadays as industrial heritage. But preservation of industrial facilities is not easy, although gradually city planning includes this type of heritage for preservation. However, landscape and city image become more complex. Sepe [6] mentions the contemporary city is the locus not only of complexity but also of simultaneity and instability, which give rise to situations of mutation and transitoriness. These are often predominantly motivated by economic gain, to the detriment of place identity which becomes increasingly compromised or unrecognizable.

Identity can also be formed by people's perception and it includes the images of a city and its architecture; thus, preservation of historic architecture can reinforce social identity. But a problem is the way societies learn to preserve iconic buildings and places. Hence, Architecture school don't teach too much about historic preservation. Wells [7] says one issue is that preservation is difficult to incorporate into architectural studios that often treat context as tangential to design and avoid the complexity of building reuse, instead favouring the theoretically pure area of new construction and design.

\section{RESULTS}

The comparison of the company towns selected for the writing of this paper shows common areas among them. Figs 1 and 2 illustrate a study of the taxonomic classification of architectural and urban characteristics of iconic textile company towns in Mexico. Administration and production areas always were the best built architectural spaces with special emphasis in the main access of the company. Very frequently, people can't imagine how beautiful some industrial heritage buildings are. In some cases, there were magnificent porticos built in stone, for example the main portico of San Ignacio was built of fine stonework white, with Gothic reminiscences on the main porch.

The design of housing for workers always was peculiar in company towns. In fact, company towns were small towns with some comfort pretentions for workers. The place used to have a small chapel, occasionally a school and the houses for workers were conveniently located neighbouring the factory. The best achieved designs, in terms of landscape architecture, were La Constancia Mexicana, La María and San Ignacio factories; thus the main façades of the buildings were those with remarkable views of the production and administration areas; but also, surrounded by the houses of workers. $4 \mathrm{~m}$ width $\times 8 \mathrm{~m}$ depth was the average size of the houses for workers.

In San Ignacio company town, the review of historical records demonstrated there were 40 houses with $30.81 \mathrm{~m}^{2}$ apiece. Also, there used to be 65 small houses with $14.40 \mathrm{~m}^{2}$ each one. It can be observed in Fig. 2 a reconstruction of housing for workers in San Ignacio Floor plan. In addition, four houses - occupied by administrators - had a surface of $50 \mathrm{~m}^{2}$ each one. Furthermore, three big houses were built with $155 \mathrm{~m}^{2}$ apiece, destined to owners and their families.

Even though houses for workers were kind of small, the total height of 4.5 m made them look bigger than what they really were. In fact, during the Viceroyalties in Mexico, especially during the 17th and 19th centuries, houses for workers were designed with enough room for 

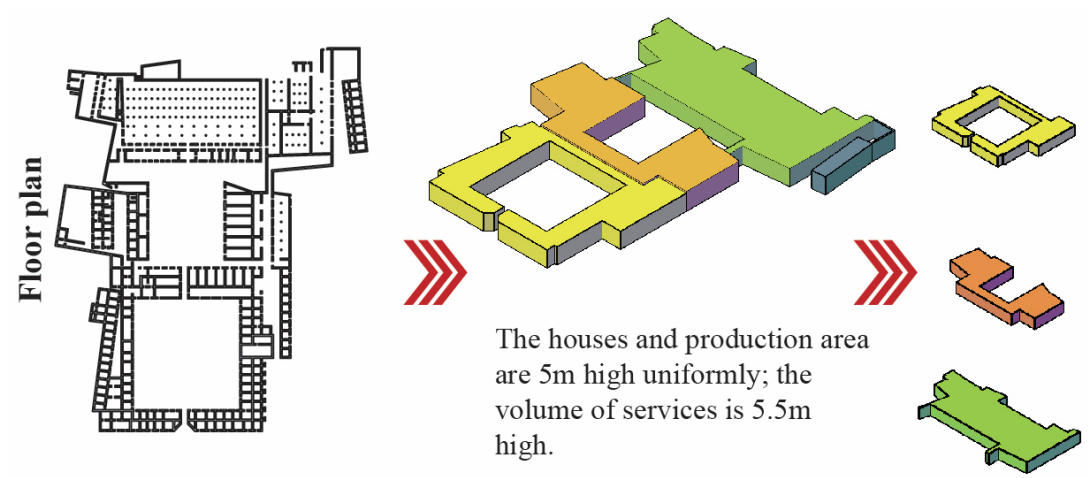

Houses for workers and services areas.

Storage and workshop areas (yarns process).

Production (fabric) and offices areas. owners.

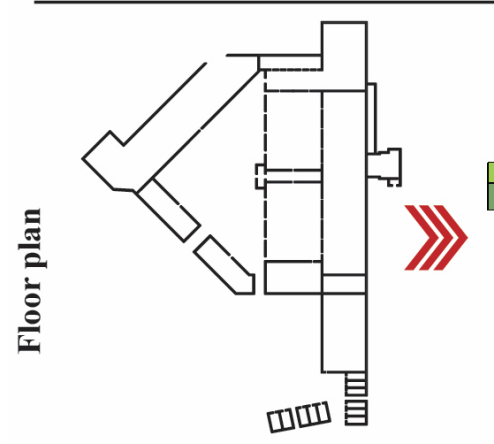

Rio Grande, El Salto - Jalisco.

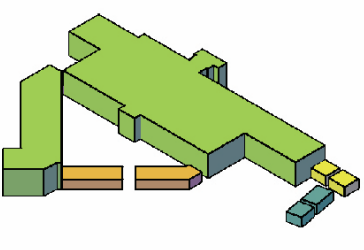

The main production area is $11 \mathrm{~m}$ high, the secondary area is $10 \mathrm{~m}$ high. The remaining areas of the complex are $4 \mathrm{~m}$ high.

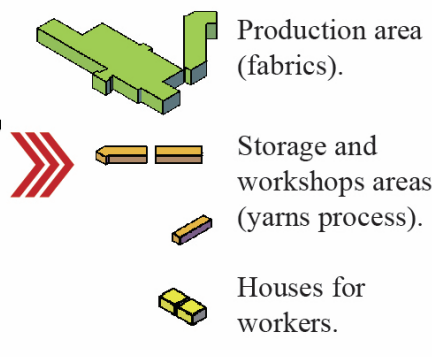

Houses for owners.
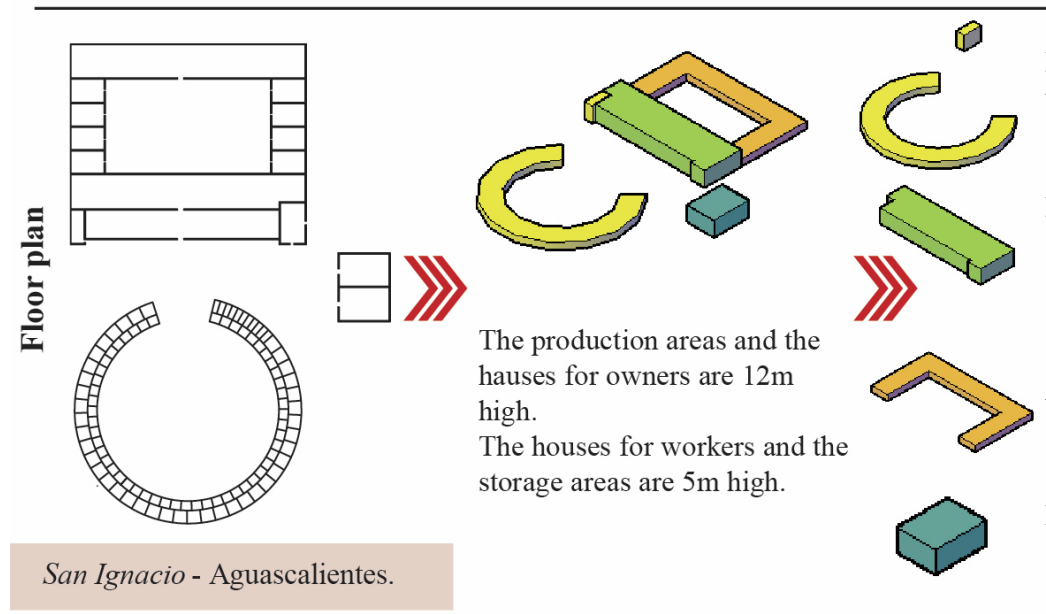

Houses for workers, services areas and a chapel.

Production

(fabrics) and offices areas.

The production areas and the hauses for owners are $12 \mathrm{~m}$ high.

The houses for workers and the

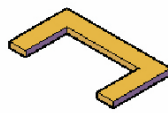

Storage areas and workshops areas (yarns process). storage areas are $5 \mathrm{~m}$ high.

Houses for owners.

Figure 2: Sample of company towns in Puebla, Jalisco and Aguascalientes. (Source: Drawing made by Alejandro Acosta Collazo and Adriana Guadalupe Martín del Campo Cervantes, September 2020.) 
a family composed of two or four people. The houses were made of stone or bricks, but some of them were also made of sun-dried bricks (adobes).

During the Industrial Revolution phase, rows of houses for workers became a usual panorama in company towns. This is the case of several factories mentioned in this paper: La Soledad, La Trinidad and La María. But also, in two cases: La Constancia Mexicana and San Ignacio, lines of houses making a main square in the centre were built. The square became a garden accessible to the workers and owners of company towns - and occasionally visitors were allowed to access to the estate property. For example, in San Ignacio company town there used to be a small lake beside the houses for workers and also the main garden, where some visitors, employees and the owners practiced leisure activities on weekends. This was a nice side of the company town facilities.

The improvements on the company towns sporadically included schools for workers; but chapels were very common buildings during the rise of the Mexican haciendas. Even though the sizes of the chapels were small, in some cases the interior decorations were remarkable. Some extraordinary baroque style chapels can be found in Mexican haciendas. Also, company towns had designers built fine altars inside the chapels.

Description of spatial distribution of industrial heritage buildings should be included in restoration projects and interpretive museum so people can understand the original designs of the buildings. But there's still a lot to do about it, Mundo et al. [8] mention post-occupancy evaluation (POE) studies of historic buildings with a new use could provide crucial information to the improvement of the building operation and satisfaction of staff and visitors. The latter will reduce staff discomfort and absenteeism while increasing their motivation to work. On the other hand, happy visitors will encourage others to visit the gallery and other converted historic buildings, which will contribute to the preservation of architectural heritage.

Storage and workshops structures were built in all the analysed cases mentioned in this paper, but they were located in diverse places of the company towns. They mainly supported the production of fabrics. Workshops included yarn process and the machines used to make fibres. In La Soledad company town, storage and workshops were kind of disseminated, but always near the administration and production areas. In the case of La Trinidad company town the storage and workshops buildings were situated beside the production area (fabrics), but lined up in orderly rows. In the case of La María company town, storage and workshops facilities were situated with the design of the main building accordingly - also lined up in rows.

La Constancia Mexicana is a good example of a European company town design variation. In such a case, the storage and workshop areas used to be situated among the houses for workers and the production buildings. This location and lay outs enhanced the manufacture of yarn and fabrics. This historical building is now being restored and an interpretive museum is getting ready to be opened to public soon. Also, there used to be a mill powered by water pressure in the factory, so the restoration works include a reconstruction of the mill. By the way, it was common to find mills in company towns that generated electricity, but in most of the cases mentioned in this paper the machines were stolen or sold out when the factories closed.

San Ignacio company town was the most magnificent industrial building located in the countryside of Aguascalientes City. Even though, most of the buildings analysed in this paper are Spanish style, in San Ignacio there used to be a French provincial style with mansard roof building. Pierre Cornú was the owner of this company and French influence was evident in the whole building design. Also, there used to be a mill powered by water pressure, but no pieces of it were found. In fact, nowadays the whole historic building is at risk of falling 
down. In addition, the city of Aguascalientes continues to grow on its western side and the newest social housing projects and private developments nearby have become a problem for the preservation of such historic building.

It can be observed taxonomic classification and typology in architecture enabled a better comparison among the most important and common components of a company town. This method also demonstrated a better understanding of how the constructors solved the original designs in accordance with the geographic locations.

\section{CONCLUSIONS}

Researching company towns still have a lot to accomplish in order to discover basic principles of their design and a theory based on architectural knowledge. Historical information of company towns can help instil and support best practices in preservation of industrial heritage. Also, recovering discussions about quotidian life in company towns can help interpretive centres to make people understand historical perspectives. This comprises interviews with former workers, historical videos of the factories or architectural spatial comparisons, as shown in this paper. Also, multimedia devices can be very helpful in interpretive museums.

The manufacturers didn't make a lot of mistakes in the design of the original company towns mentioned in this paper. In fact, architecture in every factory depended on the geographic location, climate and the latest technology advancements. In addition, it can be observed in Fig. 3, that the largest buildings of the company towns were destined to production areas. In fact, in the case of Río Grande, El Salto - Jalisco, it occupied $92 \%$ of the whole company. Although in San Ignacio, there used to be a balance between the dimensions of the production (30\%) and the workshop buildings (29\%).

The biggest company town was Río Grande with a built area of $32,000 \mathrm{~m}^{2}$, however La Constancia Mexicana $\left(9,826 \mathrm{~m}^{2}\right)$ and San Ignacio $\left(9,168 \mathrm{~m}^{2}\right)$ company towns had similar built areas. Also, the built zones destined to houses for workers were from $16 \%$ to $34 \%$ of the total built areas in each case, but not in Río Grande.

The adaptive reuse projects in preservation of company towns are important, but they ought to respect the original structures and aesthetics of the historic buildings. If administrators of such recovered buildings have to charge the entrance to visitors, the fee depends on the quality of services they offer, Moreno-Mendoza et al. [9] report there are differences between if the users understand that it is necessary to invest more or not in heritage, if they enjoy museums in books or TV, or if it is necessary to charge more expensive entry to offer improvements. It also follows that the visitor does not mind paying if their degree of satisfaction meets the expectations he had regarding the visit to the museum.

Depending on the cultural understandings of visitors, historic buildings can be perceived as part of the reuse projects. Thus, showing people, in designated specific rooms, how the company towns used to function - including its components, as presented in this paper - can allow site visitors to better understand the values of a company town.

Even though not all the abandoned industrial sites require to be restored; hence, the governments and researchers can select which buildings and places should be recovered. For example, Heaphy and Wiig [10] argue that former industrial areas, docks and warehouses, railroad embankments, car parks, and low-cost older residential blocks and houses are being replaced with high-end office spaces, higher density, opulent apartment blocks, and the corresponding amenities for a more lucrative demographic.

Also, if governments promote restoration and reuse of historic company towns, they also promote a circular economy. Foster [11] says all cultural heritage buildings and their adaptive 
Soledad Vista Hermosa - Oaxaca

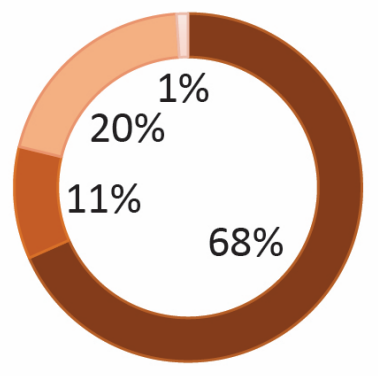

La Constancia Mexicana Puebla

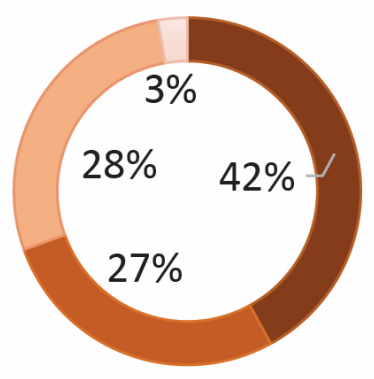

La Trinidad - Tlaxcala

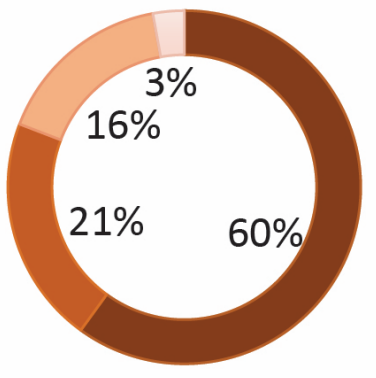

Río Grande, E1 Salto - Jalisco

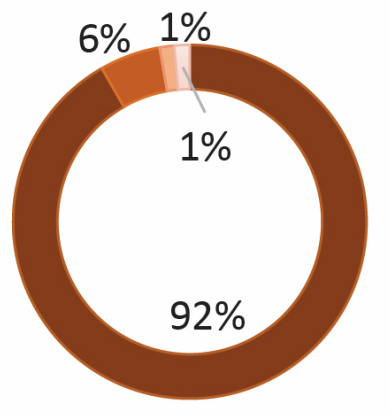

La María - Puebla

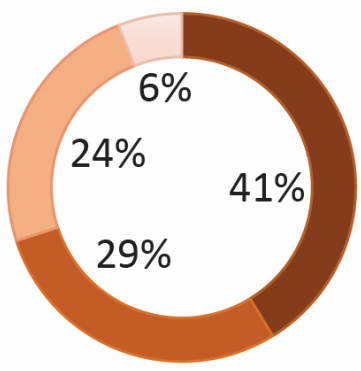

San Ignacio - Aguacalientes

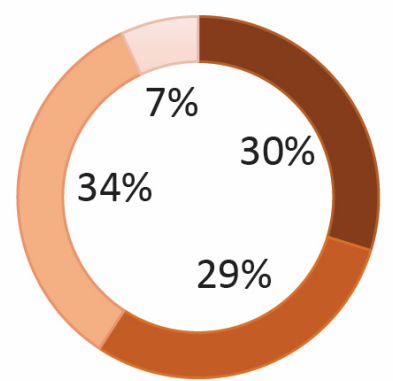

n Production areas m2

n Storage and workshop areas m2

$\square$ Housing for workers and services $\mathrm{m} 2$

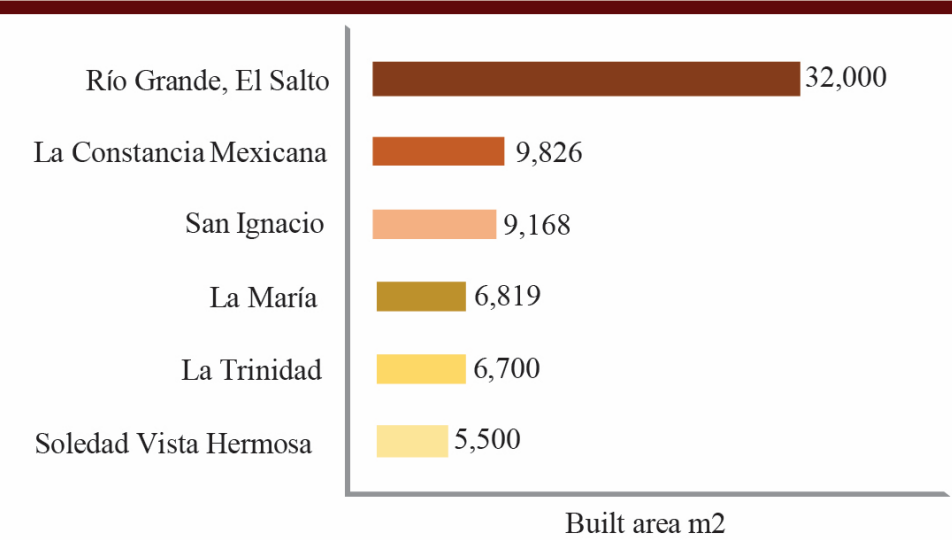

Figure 3: Comparison of company towns in Mexico. (Source: Drawing made by Alejandro Acosta Collazo and Adriana Guadalupe Martín del Campo Cervantes, September 2020.) 
reuses are unique, place-based and community-based, meaning that a universal solution is impossible. This challenge may be obvious; nevertheless, it is significant. A consequence is that the strategies serve conflicting goals.

Finally, Calderón et al. [12] argue the tourism potential of a region requires, in the first place, an evaluation of its capabilities. So, it's convenient to think about the location of company towns to be restored and all their peculiarities, in order to adjust the adaptive reuses to what tourists expect to learn by visiting such historical places. In addition, preservation of company towns in Mexico can also be instrumental in developing cultural identity.

\section{ACKNOWLEDGEMENTS}

I thank my research assistant Adriana Guadalupe Martín del Campo Cervantes. I also thank the students: Luis Ariel Zúñiga Guerrero and Lucía Sucunza Dávalos. Appreciation is extended to my colleague and researcher: Marco Alejandro Sifuentes Solís.

\section{REFERENCES}

[1] Marais, L., McKenzie, F., Deacon, L., Nel, E. \& van Rooyen, J.C., The changing nature of mining towns: Reflections from Australia, Canada and South Africa. Land Use Policy, 76, pp. 779-788, 2018. https://doi.org/10.1016/j.landusepol.2018.03.006.

[2] Yuan, Z., Zheng, X., Lv, L. \& Xue, C., From design to digital model: A quantitative analysis approach to garden cities theory. Ecological Modelling, 289, pp. 26-35, 2014. https://dx.doi.org/10.1016/j.ecolmodel.2014.06.015.

[3] Groat, L.N. \& Wang, D., Architectural Research Methods, 2nd ed., John Wiley: New Jersey and Canada, p. 222, 2013.

[4] Shojae, S.H., Islami, S.G. \& Rezaei, M., Role of local and urban textures in promoting social interactions of residents and emphasizing living centers theory of Christopher Alexander. Frontiers of Architectural Research, p. 13, 2020. https://doi.org/10.1016/j.foar.2020.05.008.

[5] Camerin, F., From "Ribera Plan" to "Diagonal Mar", passing through 1992 "Vila Olímpica". How urban renewal took place as urban regeneration in Poblenou district (Barcelona). Land Use Policy, 89, p. 12, 2019.

https://doi.org/10.1016/j.landusepol.2019.104226.

[6] Sepe, M., Regenerating places sustainability: The healthy urban design. International Journal of Sustainable Development, 15(1), p. 25, 2020.

https://doi.org/10.2495/SDP-V15-N1-14-27.

[7] Wells, J.C., Challenging the assumption about a direct relationship between historic preservation and architecture in the United States. Frontiers of Architectural Research, 7(4), p. 458, 2018. https://dx.doi.org/10.1016/j.foar.2018.10.001.

[8] Mundo, J., Valerdi, M.C. \& Sosa, J., Post-occupancy evaluation of a restored industrial building: A contemporary art and design gallery in Mexico. Frontiers of Architectural Research, 4(4), p. 339, 2015. https://dx.doi.org/10.1016/j.foar.2015.09.003.

[9] Moreno-Mendoza, H., Santana-Talavera, A. \& Boza-Chirino, J., Perception of governance, value and satisfaction in museums from the point of view of visitors: Preservation-use and management model. Journal of Cultural Heritage, 41, p. 186, 2020. https://doi.org/10.1016/j.culher.2019.06.007.

[10] Heaphy, L. \& Wiig, A., The 21 st century corporate town: The politics of planning innovation districts. Telematics and Informatics, 54, p. 1, 2020.

https://doi.org/10.1016/j.tele.2020.101459. 
[11] Foster, G., Circular economy strategies for adaptive reuse of cultural heritage buildings to reduce environmental impacts. Resources, Conservation and Recycling, 152, p. 11, 2020. https://doi.org/10.1016/j.resconrec.2019.104507.

[12] Calderón, D.M., Arcila, M. \& López, J.A., Methodological proposal for the elaboration of a tourist potential index applied to historical heritage. International Journal of Sustainable Development and Planning, 15(3), p. 295, 2020.

https://doi.org/10.18280/ijsdp.150305. 